\title{
Studies on the Activation of Sphingomyelinase Activity in Niemann-Pick Type A, B, and C Fibroblasts: Enzymological Differentiation of Types A and B
}

\author{
A. POUlOS, E. RANIERI, P. SHANKARAN, AND J. W. CALLAHAN \\ Department of Chemical Pathology, The Adelaide Children's Hospital Inc., North Adelaide, South Australia, \\ 5006 [A.P., E.R.] and Neurosciences Department, Research Institute, Hospital for Sick Children, \\ Toronto, Ontario, Canada [P.S., J.W.C.]
}

\begin{abstract}
Cultured skin fibroblast homogenates from patients with Niemann-Pick disease Type $C$, were able to degrade sphingomyelin liposomes at a normal rate. Fibroblasts from patients with Niemann-Pick disease Types $A$ and $B$ were less active $(0.08-0.55$ versus $0.96-2.93 \mathrm{nmol} /$ $\mathrm{h} / \mathrm{mg}$ ). When fibroblasts were maintained in synthetic media (MCDB-104) devoid of fetal calf serum for a period of 21 days, sphingomyelinase activity measured at pH 3.8 increased in control and Niemann-Pick Type $C$ (up to 15fold) and in Niemann-Pick Type B (up to 3-fold) while Niemann-Pick Type A showed no significant increase in sphingomyelinase activity.

Addition of a protein activator isolated from the spleen of a Type I Gaucher's disease patient stimulated a 2-7.5fold increase in sphingomyelinase activity in normal, Niemann-Pick Type $B$ and $C$ fibroblasts, while under the same conditions the Niemann-Pick Type A fibroblast enzyme responded poorly.

Our data show that the residual sphingomyelinase activity in Niemann-Pick Type $A$ can be differentiated from that present in other phenotypic forms by its lack of response to the Gaucher activator. Furthermore, we can find no evidence to support the view that Niemann-Pick Type $C$ sphingomyelinase differs from the normal enzyme in its response to Gaucher activator. (Pediatr Res 18:10881093, 1984)
\end{abstract}

Cultured skin fibroblasts from patients with Niemann-Pick disease Types A and B show an almost total deficiency in sphingomyelinase activity in vitro (1). Cells from patients with the juvenile neuronopathic form of Niemann-Pick disease Type $C$, however, display either a moderate attenuation of enzyme activity or have normal activity $(11,15,16,21)$. However, although the residual activity in Niemann-Pick disease Type A and B cells is similar, the latter are clearly capable of metabolizing exogenous sphingomyelin, albeit at a significantly reduced rate $(2,13)$; in contrast, Niemann-Pick disease Type A cells are unable to degrade sphingomyelin added to the culture medium. These results suggest that subtle differences may exist between the abnormal enzymes in these two variant forms of the disorder but that the assay conditions used may not be suitable for the

Received August 15, 1983; accepted April 10, 1984. detection of these differences in vitro. One possible explanation is that the nonionic detergent Triton X-100, which has been included in most in vitro assay systems, appears to interact with the enzyme, thereby altering some of its physicochemical properties $(3,12)$. It was thus considered likely that the presence of Triton would mask any differences in the mutant enzyme activities in Niemann-Pick Type A and B cells.

Table 1. Cell lines and phenotype of donor

\begin{tabular}{|c|c|c|}
\hline Cell line & Donor age and major clinical findings & Classification \\
\hline GM 112 & $\begin{array}{l}\text { 10-month male. Hepatosplenomegaly, } \\
\text { motor and mental deterioration. }\end{array}$ & A \\
\hline GM 370 & $\begin{array}{l}\text { 13-month female. Hepatosplenomeg- } \\
\text { aly, motor and mental deteriora- } \\
\text { tion. }\end{array}$ & A \\
\hline SF 705 & $\begin{array}{l}\text { 14-yr-female. Short stature, hepato- } \\
\text { splenomegaly. }\end{array}$ & B \\
\hline SF 1126 & 22-month male. Hepatosplenomegaly. & B \\
\hline SF 1443 & 22-month male. Hepatosplenomegaly. & B \\
\hline SF 1013 & $\begin{array}{l}\text { 5-yr female. Hepatosplenomegaly, os- } \\
\text { teoporosis, pulmonary changes. }\end{array}$ & B \\
\hline SF 1384 & $\begin{array}{l}\text { 19-yr male. Splenomegaly, hemolytic } \\
\text { anemia, pes cavus, and muscle } \\
\text { wasting of lower limbs. }\end{array}$ & B \\
\hline GM 3123 & $\begin{array}{l}\text { 9-yr female. Splenomegaly, motor de- } \\
\text { terioration. }\end{array}$ & $\mathrm{C}$ \\
\hline GM 110 & $\begin{array}{l}10 \text {-yr male. Mental and motor deteri- } \\
\text { oration. Sibling died of Niemann- } \\
\text { Pick disease Type C. }\end{array}$ & $\mathrm{C}$ \\
\hline SF 1172 & $\begin{array}{l}\text { 19-yr male. Vertical supranuclear } \\
\text { ophthalmoplegia, splenomegaly, } \\
\text { motor and mental deterioration, } \\
\text { sea-blue histiocytes in bone mar- } \\
\text { row. }\end{array}$ & $\begin{array}{l}\text { Neurovisceral } \\
\text { lipidosis or } \\
\text { C }\end{array}$ \\
\hline SF 1597 & $\begin{array}{l}\text { Neonatal onset. Hepatosplenomegaly, } \\
\text { ascites. }\end{array}$ & $\mathrm{C}$ \\
\hline
\end{tabular}

We have recently developed an in vitro assay for sphingomyelinase activity based on the use of sphingomyelin liposomes rather than Triton lipid micelles as substrate $(18,20)$. In this communication, we report on the results of assays performed under these conditions, and in the presence of a natural protein activator isolated from Gaucher spleen. Our data indicate that Niemann-Pick disease Type B and C, in contrast to Niemann- 
Pick disease Type A, cells respond to activator in an essentially normal fashion. In addition, our data do not support the view that Niemann-Pick Type $C$ results from a deficiency in activator protein $(1,7)$.

\section{MATERIALS AND METHODS}

Cultured skin fibroblasts used for these studies were either obtained from the Human Mutant Cell Repository (GM 370, GM 112, GM 3112, GM 110, GM 3393), or were referred to us from clinicians throughout Australia (SF 705, SF 1126, 1447, $1384,1013,1384$ and 1172). In some instances, cell lines were generously provided by Dr. J. W. Callahan, Research Institute, Toronto, Canada. The various cell lines employed are shown in Table 1. Diagnosis of Niemann-Pick disease Types A and B was based on clinical, histological, enzymological, and, if at all possible, on chemical analysis of tissue samples. Diagnosis of Niemann-Pick disease Type $\mathrm{C}$ was based largely on clinical evidence (6) and, wherever possible, on histological confirmation of the presence of foam cells and/or sea-blue histiocytes in bone marrow or, occasionally, in a rectal biopsy. Postmortem material was not always available to confirm the storage of sphingomyelin in this group of patients.

Cell culture. Unless stated otherwise in the text, skin fibroblasts were cultured in basal Eagle's medium containing $10 \%$ fetal calf serum until confluent and were then harvested. For some experiments, the medium from confluent cells was replaced with
MCDB-104 medium (10) and the cells were maintained in the absence of fetal calf serum for 2-3 wk before harvesting. Cells were harvested by trypsinization and were then suspended in $0.25 \mathrm{M}$ sucrose by sonicating for $10 \mathrm{~s}$ at $4^{\circ} \mathrm{C}$ with an Ystrom ultrasonicator. The sonicated suspensions were used for all enzyme studies; the protein concentration of these suspensions assayed as described by Bradford (5) varied from $1-4 \mathrm{mg} / \mathrm{ml}$.

Sphingomyelinase assays. All assays were performed with liposomes of [methyl $\left.-{ }^{14} \mathrm{C}\right]$ sphingomyelin prepared as follows. $\left[{ }^{14} \mathrm{C}\right]$ Sphingomyelin $(800,000 \mathrm{dpm}, 51 \mathrm{mCi} / \mathrm{mmol})$ and unlabeled bovine brain sphingomyelin $(800 \mathrm{nmol})$ were suspended in $800 \mu \mathrm{l}$ water by ultrasonication for $25-30 \mathrm{~min}$ at room temperature until the suspension became clear. Reaction mixtures contained an aliquot of this suspension $(10 \mu \mathrm{l})$, acetate buffer pH 3.8 or $4.2(50 \mathrm{mM})$, fibroblast homogenate $(20-50 \mu \mathrm{g}$ protein), and activator protein $(0-10 \mu \mathrm{g})$ in a final incubation volume of $100 \mu \mathrm{l}$. For $\mathrm{pH}$ versus activity studies, the buffers used were $50 \mathrm{mM}$ acetate ( $\mathrm{pH} 3.6-5.0$ inclusive) and $50 \mathrm{mM}$ Trismaleate ( $\mathrm{pH}$ 5.5-8.5 inclusive). Incubation mixtures were incubated for $2 \mathrm{~h}$ at $37^{\circ} \mathrm{C}$. Released $\left[{ }^{14} \mathrm{C}\right]$ phosphorylcholine was measured as described by Poulos and Beckman (17).

Preparation of activator. Activator was isolated from Gaucher spleen as described by Peters et al. (14) with some modifications (20). For some experiments, activator which had been purified up to and including the DE-52 cellulose step was used in assays (activator preparation $\mathrm{A}$ ). In other cases, the purification procedure was continued up to and including the Sephacryl G-200
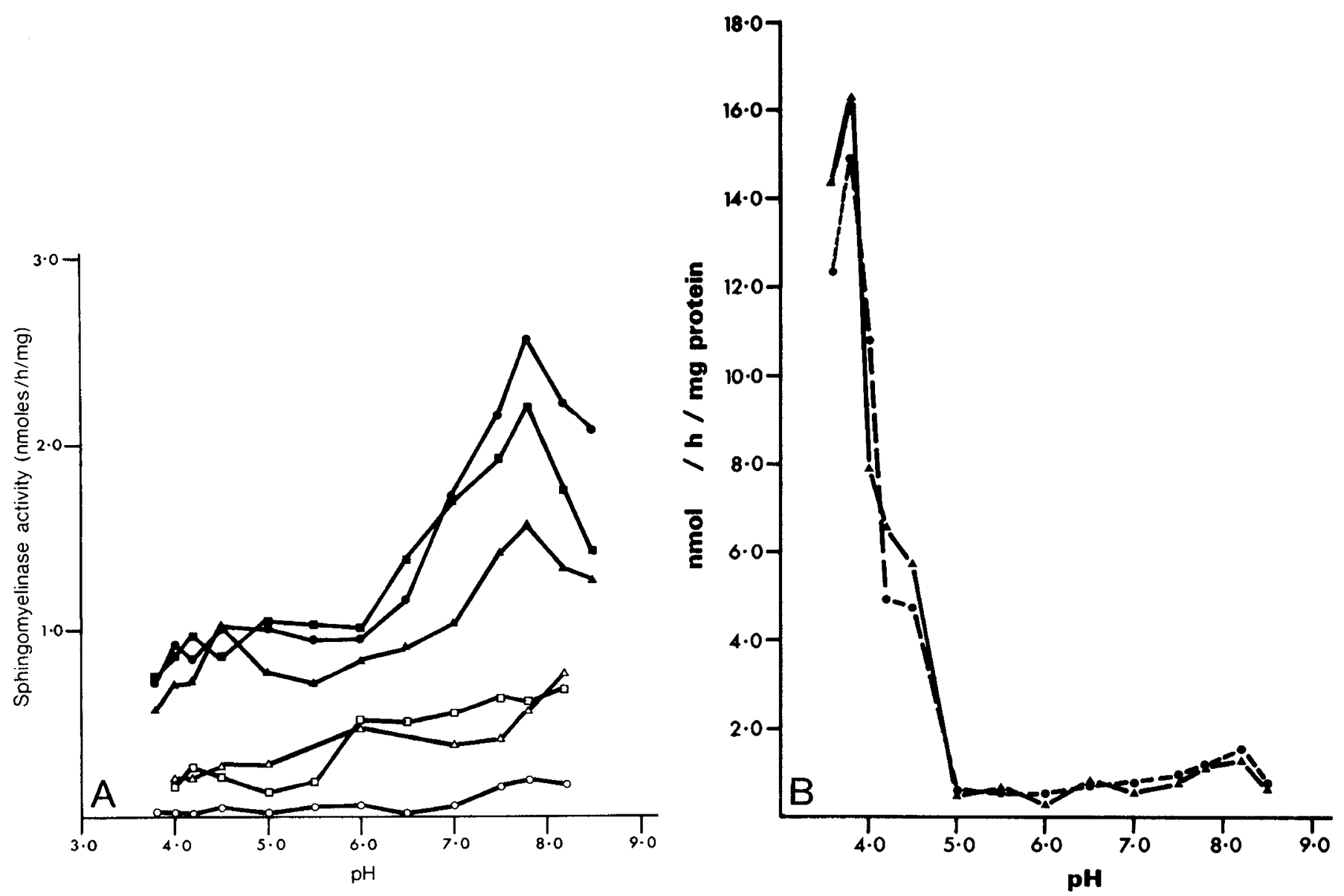

Fig. 1. Activity of sphingomyelinase as a function of $\mathrm{pH}$ in normal and Niemann-Pick fibroblasts. $A$, sphingomyelinase activity was measured in homogenates of Niemann-Pick Type A (GM 112, O), Niemann-Pick Type B (SF 705, $\square$; SF 1126, $\triangle$ ), Niemann-Pick Type C (GM 3123, O; SF $1172, \mathbf{\square})$, and control $(\boldsymbol{\Delta})$ fibroblasts as described in the text except for the described substitution of the buffers. The cells had been previously cultured in basal Eagle's medium containing $10 \%$ fetal calf serum. $B$, sphingomyelinase activity was measured in homogenates of Niemann-Pick Type C (SF 1 172, ---) and control fibroblasts (A_-A) previously maintained in MCDB-104 medium devoid of fetal calf serum. 
column chromatography step as described (20). Active fractions from the Sephacryl G-200 gel filtration were pooled, dialyzed exhaustively against water at $4^{\circ} \mathrm{C}$, and then freeze-dried. The residue was then redissolved in $10 \mathrm{mM}$ Tris- $\mathrm{HCl}$ buffer, $\mathrm{pH} \mathrm{7.0,}$ containing $20 \%$ glycerol to give a final protein concentration of $1-2 \mathrm{mg} / \mathrm{ml}$. Aliquots of this solution were also used as a source of activator and are referred to in the text as activator preparation $\mathrm{B}$.

Table 2. Sphingomyelinase activity in normal and NiemannPick disease fibroblasts

\begin{tabular}{clc}
\hline & \multicolumn{2}{c}{$\begin{array}{c}\text { Sphingomyelinase activity } \\
\text { (nmol/h/mg protein) }\end{array}$} \\
\cline { 2 - 3 } Cell type & \multicolumn{1}{c}{$\begin{array}{c}\text { With } \\
\text { fetal calf serum }\end{array}$} & $\begin{array}{c}\text { Without } \\
\text { fetal calf serum }\end{array}$ \\
\hline Niemann-Pick disease Type A & & \\
GM 112 & 0.37 & 0.32 \\
GM 370 & $0.10,0.31$ & 0.31 \\
Niemann-Pick disease Type B & & \\
SF 705 & $0.32,0.16,0.51$ & 0.71 \\
SF 1443 & $0.13,0.14,0.41$ & 0.50 \\
SF 1384 & $0.22,0.43$ & 0.62 \\
SF 1013 & $0.17,0.46$ & 0.44 \\
SF 1126 & 0.08 & NM* \\
Niemann-Pick disease Type C & & \\
SF 1597 (neonatal) & $2.4,0.71$ & NM \\
GM 110 (early onset) & 2.3 & 8.9 \\
SF 1172 (late onset) & 1.0 & 14.9 \\
Control range $(n=6)$ & $0.96-2.93$ & $4.1-16.4$ \\
\hline
\end{tabular}

* NM, not measured. Sphingomyelinase activity was measured using liposomes of $\left[{ }^{14} \mathrm{C}\right]$ sphingomyelin as a substrate. Fibroblasts were either cultured in basal Eagle's medium containing $10 \%$ fetal calf serum or MCDB-104 medium, without fetal calf serum, as described in the text.

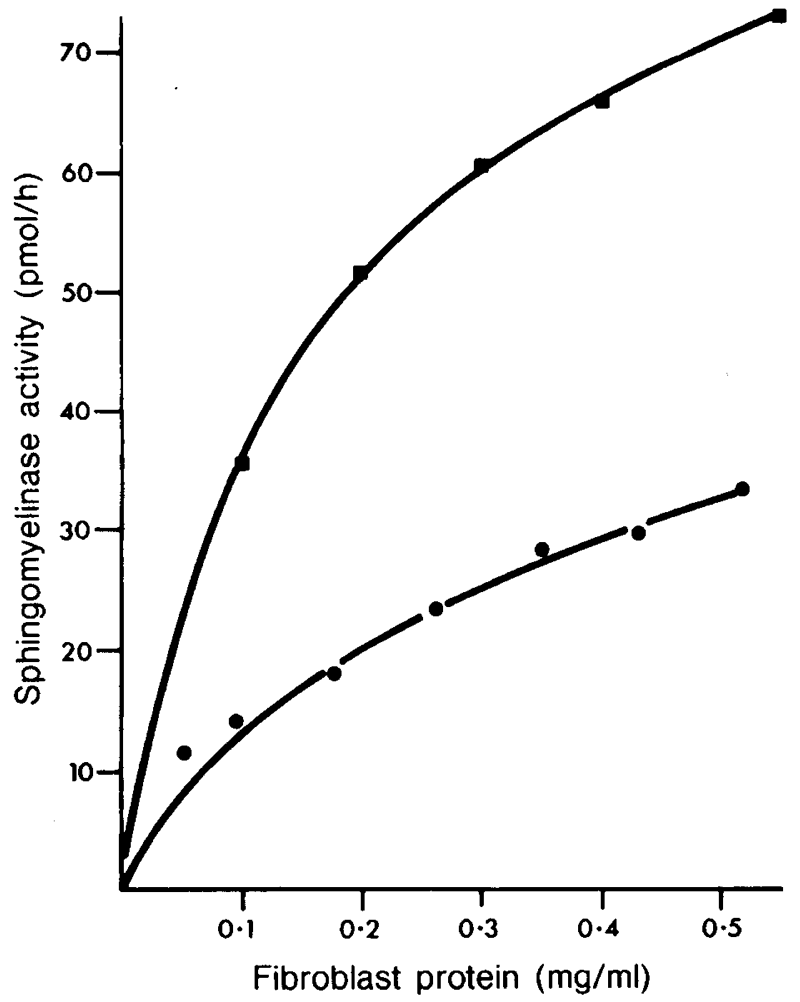

Fig. 2. Activity of sphingomyelinase as a function of fibroblast protein concentration. Sphingomyelinase activity was measured in homogenates from two separate normal fibroblast lines as described in the text.

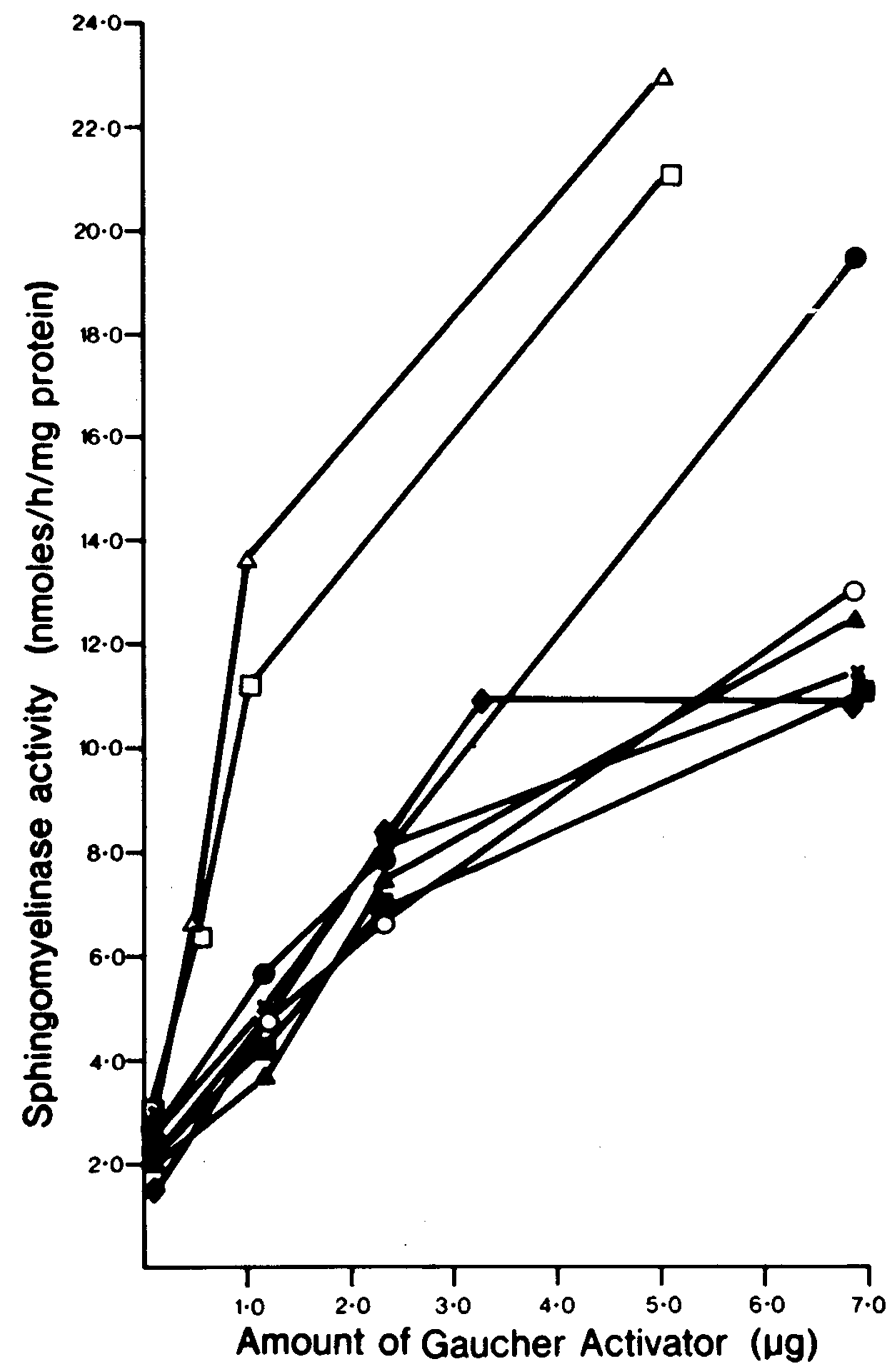

Fig. 3. Effect of purified activator on the sphingomyelinase activity in normal and Niemann-Pick Type $\mathrm{C}$ fibroblasts. Sphingomyelinase activity was measured in homogenates of normal $(O, \square, \mathbf{0}, \mathbf{\Delta}$, and $\mathbf{\square})$ and Niemann-Pick Type C (GM 3123, $\triangle$; SF 1597, ×; SF 1172, fibroblasts in the presence of varying amounts of Gaucher activator (preparation B).

\section{RESULTS}

Normal fibroblasts grown in basal Eagle's medium containing $10 \%$ fetal calf serum show two $\mathrm{pH}$ optima for the hydrolysis of sphingomyelin liposomes, one at $\mathrm{pH} \mathrm{4.2-4.4} \mathrm{and} \mathrm{the} \mathrm{other} \mathrm{at}$ $\mathrm{pH}$ 7.5-8.5. Under the same conditions, a similar $\mathrm{pH}$ versus activity profile is shown by fibroblasts from patients with the early and late onset forms of Niemann-Pick disease Type C (Fig. 1). Niemann-Pick Type A and B fibroblasts, however, were deficient at both $\mathrm{pH}$ optima, although considerable activity was detected in some of these lines. The specific activities of normal as well as mutant cell lines varied significantly according to the cell culture employed. Activities within individual cultures of both Niemann-Pick Type A and B fibroblasts, for example, at times approached $50 \%$ of the activity shown by normal cells (Table 2). A major cause of this variability seemed to relate to the degree of confluence of the cells, very confluent cells showing greater activity.

The specific activity of the enzyme also varied according to the incubated protein concentration (Fig. 2). Because of the nonlinearity of the reaction, a constant fibroblast protein concentration $(0.40-0.50 \mathrm{mg} / \mathrm{ml})$ was employed for all assays.

When normal fibroblasts were maintained in MCDB-104 me- 
dium devoid of fetal calf serum (see "Materials and Methods") their acidic sphingomyelinase activity increased markedly; concomitantly, the $\mathrm{pH}$ optimum decreased significantly from $\mathrm{pH}$ 4.2-4.4 (Fig. $1 A$ ) to $\mathrm{pH} 3.8-4.0$ (Fig. $1 B$ ). A corresponding change in the activity and the $\mathrm{pH}$ optimum was observed for fibroblasts from the adult (SF 1172, Fig. 1B) and early onset forms of Niemann-Pick disease Type C. Under these conditions, the acidic sphingomyelinase activity of Niemann-Pick Type B
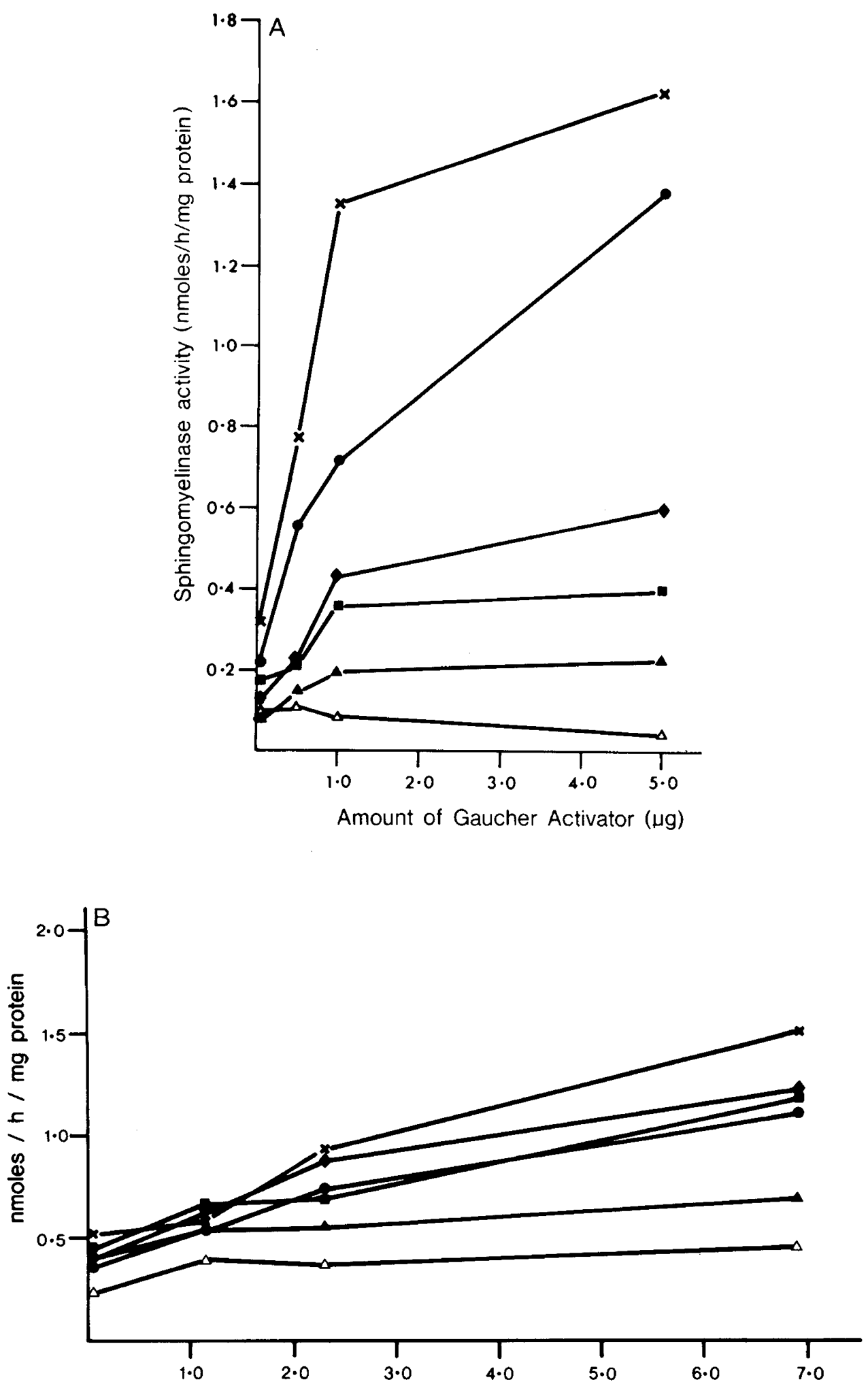

Amount of Gaucher Activator $(\mu \mathrm{g})$

Fig. 4. Effect of Gaucher activator on the sphingomyelinase activity of Niemann-Pick Type A and B fibroblasts. $A$, sphingomyelinase activity was measured in homogenates of Niemann-Pick Type A (GM 370, $\triangle$ ) and Niemann-Pick Type B (SF 705, X; SF 1384, $\mathbf{0}$; SF 1443, $\bullet$; SF 1013, $\mathrm{SF} 1126, \boldsymbol{\Delta})$ fibroblasts in the absence and in the presence of varying amounts of activator isolated from Gaucher spleen (preparation $\mathrm{B}$ ). $B$, conditions were the same as in $A$ except for the use of different subcultures of the various cell lines. 


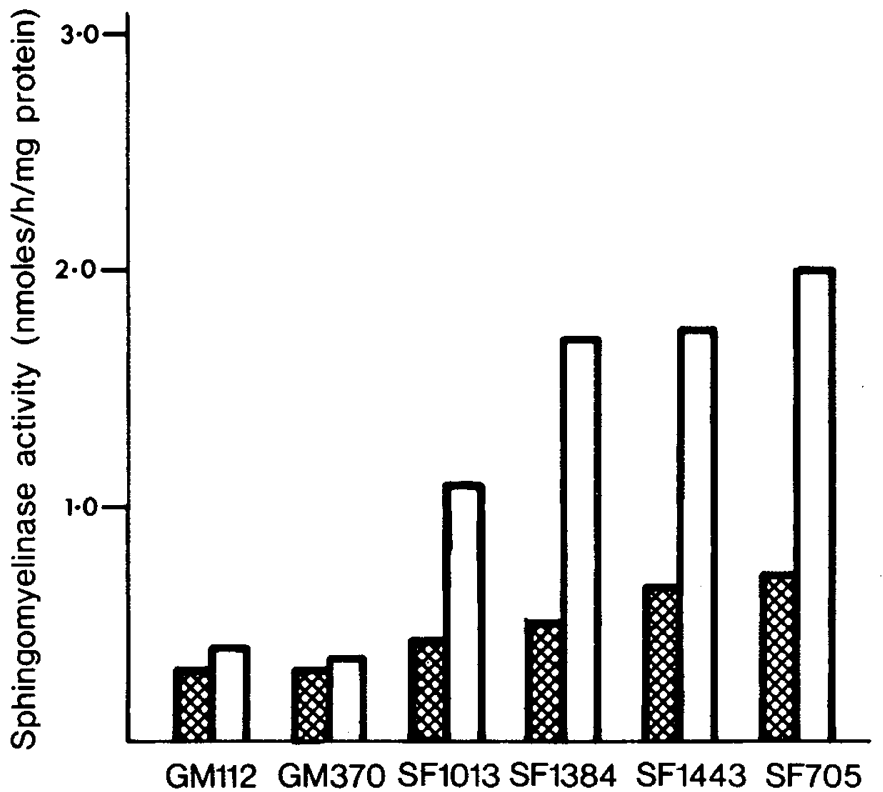

Fig. 5. Effect of Gaucher activator on the sphingomyelinase activity of Niemann-Pick Type A and B fibroblasts previously maintained in medium free of fetal calf serum. Sphingomyelinase activity was measured in homogenates of fibroblasts previously maintained for $3 \mathrm{wk}$ without fetal calf serum on MCDB-104 medium in the absence (hatched) and in the presence (open) of varying amounts of activator. The activation shown was obtained using $7 \mu \mathrm{g}$ activator protein.

but not Type A fibroblasts also increased, but to a lesser degree (Table 2). The increase in activity observed in fibroblasts cultured in MCDB-104 medium was not confined to sphingomyelinase alone as it was also noted for a number of other lysosomal enzymes including $\beta$-galactocerebrosidase, $\beta$-galactosidase, and acid-phosphatase.

Addition of the purified activator isolated from Gaucher spleen to incubation mixtures stimulated a dose-dependent increase in activity of the acidic sphingomyelinase. Fibroblasts from patients with the neonatal, early onset and late onset variant forms of Niemann-Pick disease Type $C$ responded to activator in an identical fashion (Fig. 3). Figure 4, $A$ and $B$, shows the response to activator of cells from two different subcultures of NiemannPick disease Types A and B. Residual activity in Type B fibroblasts varied in its response to activator both according to the cell line and to the subculture employed. Sphingomyelinase activity of Niemann-Pick Type A fibroblasts, however, responded poorly to activator in both subcultures tested. This apparent differentiation of the neuronopathic and non-neuronopathic forms of Niemann-Pick disease was more pronounced when the response to activator was studied in cells maintained in MCDB-104 medium (Fig. 5). The acidic sphingomyelinase activity in Niemann-Pick Type B fibroblasts grown under these conditions was clearly more responsive to activator than that present in Type A fibroblasts.

\section{DISCUSSION}

Our data show clearly that sphingomyelinase activity can be detected in cultured skin fibroblasts from normal individuals when the substrate is prepared in a liposomal form and the enzyme activity is measured in the absence of detergents. Moreover, activity can be observed even in extracts from patients with Niemann-Pick disease Types $\mathrm{A}$ and $\mathrm{B}$, activities ranging from approximately 0.08 to $0.5 \mathrm{nmol} / \mathrm{h} / \mathrm{mg}$ protein. These values represent $10-50 \%$ of the activity detected in control cell lines. The relatively high degree of residual activity is somewhat surprising particularly in view of the low activity observed when assays are performed in the presence of detergents such as Triton $\mathrm{X}-100(17)$. The most likely explanation is that this activity is not due to the action of a lysosomal sphingomyelinase but rather results from an attack by a nonspecific phosphodiesterase such as that, for example, which cleaves bis(4-methylumbelliferyl) phosphate in the absence of Triton X-100 (4). The proportionally much greater stimulation of normal as opposed to both Type A and $\mathrm{B}$ fibroblast sphingomyelinase activities supports this view. Maintenance of cells in MCDB-104 medium devoid of fetal calf serum induces a marked increase in activity of a number of lysosomal enzymes and concomitantly leads to the increase in individual cells of vacuoles also suggesting an increase in lysosomal activity (unpublished results). The data shown in Figures 3 and 4 demonstrate that the activity present in normal, Niemann-Pick Type B, and Niemann-Pick Type $C$ cells is stimulated quite significantly by purified Gaucher spleen activator. The two Niemann-Pick Type A cell lines examined, on the other hand, responded poorly, suggesting that the residual activity differs in some way from that found in the other cell lines. In the presence of activator, the residual Niemann-Pick Type B sphingomyelinase activity is stimulated to values which approach those shown by normal cells (i.e. when measured in the absence of activator) indicating that the in vivo activity may be sufficient to catabolize a sizeable proportion of the cellular sphingomyelin, providing endogenous stores of activator are elevated. These results confirm the apparent ability of fibroblasts, in culture, to degrade exogenous sphingomyelin $(2,13)$. The accumulation of sphingomyelin in the liver and spleen of Type B patients may thus be explained by postulating that the attenuated enzyme activity cannot cope in those tissues, such as liver and spleen, in which there is a rapid turnover of membrane lipids. The data shown in Figure 4 suggest that the degree of residual sphingomyelinase activity varies even within patients with Niemann-Pick disease Type B and may ultimately explain why some patients present with hepatosplenomegaly very early in life, while others may not present till much later $(6,19)$.

It is not known, at present, why the residual activities in Type $A$ and $B$ fibroblasts differ in their response to activator. In an analogous disease state, i.e. Gaucher's disease, it has been suggested that the differences may relate to the degree of processing undergone by the mutant enzymes and to the site of the mutation (9). In contrast to the mutant enzyme in tissue from patients with the non-neuronopathic form of the disease (Type I), the enzyme in patients with neuronopathic (Type II) form appears to be incompletely processed. Whether these observations are of relevance in Niemann-Pick disease must await a more detailed study of the mutant enzymes.

We are unable to confirm that sphingomyelinase in fibroblasts from patients with the chronic neuronopathic form of NiemannPick disease (Type $\mathrm{C}$ ) is more responsive to activator than the normal enzyme as claimed by Christomanou (7). Figure 3 shows that the normal and Niemann-Pick disease Type C fibroblasts respond in a similar fashion to the addition of varying amounts of highly purified activator; in addition, we are unable to confirm the low residual activity observed by this worker. One possible explanation for our inability to confirm these earlier observations is that there may be genetic heterogeneity in this group of disorders, a hypothesis supported by the marked diversity in clinical phenotypes $(6,19)$ and by the ultrastructural differences observed in cultured skin fibroblasts from these patients (8). A more rigorous analysis of the hypothesis that the defect in Niemann-Pick disease Type $C$ is due to an inherited deficiency in an activator protein must await the development of better analytical techniques for their detection and quantitation in a variety of tissue sources.

\section{REFERENCES}

1. Baraton G, Revol A 1977 Activators for sphingomyelinase and the nature of the sphingomyelinase deficiency in Niemann-Pick disease Type A, B and C. Clin Chim Acta 76:339

2. Beaudet AL, Manschrek AA 1982 Metabolism of sphingomyelin by intact 
cultured fibroblasts: differentiation of Niemann-Pick disease Types A and B. Biochem Biophys Res Commun 105:14

3. Besley GTN 1976 The effect of Triton X-100 on the isoelectric focussing profile of fibroblast sphingomyelinase. FEBS Lett 72:101

4. Besley GTN 1978 Diagnosis of Niemann-Pick disease using a simple and sensitive fluorimetric assay of sphingomyelinase activity. Clin Chim Acta 90:269

5. Bradford M 1976 A rapid and sensitive method for the quantitation of microgram quantities of protein utilizing the principle of protein-dye binding. Anal Biochem 72:248

6. Brady RO 1978 In: Stanbury JD, Wyngaarden JB, Grederickson DS (eds) The Metabolic Basis for Inherited Disease, McGraw-Hill, New York, 4th ed, pp $718-730$

7. Christomanou H 1980 Niemann-Pick disease, Type C. Evidence for the deficiency of an activating factor stimulating sphingomyelin and glucocerebroside degradation. Z Physiol Chem 361:1489

8. Ellis DH, Jaunzems AE, Poulos A, Carey WF 1982 Ultrastructural studies on cultured fibroblasts from patients with lipid storage disorders. Proceedings of Human Genetics Society of Australia, Adelaide (Pathology 15:103)

9. Ginns EJ, Brady RO, Pirruccello S, Moore C, Sorrell S, Furbish FS, Murray GJ, Tager J, Barranger JA 1982 Mutations of glucocerebrosidase: discrimination of neurologic and non-neurologic phenotypes of Gaucher Disease. Proc Natl Acad Sci USA 79:5607

10. Ham RG, McKeeham WL 1978 Development of improved media and culture conditions for clonal growth of normal diploid cells. In Vitro 14:11

11. Huterer S, Wherrett JR, Poulos A, Callahan JW 1983 Deficiency of phospholipase $C$ acting on phosphatidyl glycerol in Niemann-Pick disease. Neurology 33:67

12. Jones CS, Shankaran P, Davidson DJ, Poulos A, Callahan JW 1983 Studies on the structure of sphingomyelinase: amino acid composition on isoelectric focussing. Biochem J 209:291

13. Maziere JC, Maziere C, Mora L, Routier JD, Polonovski J 1982 In situ degradation of sphingomyelin by cultured normal fibroblasts and fibroblasts from patients with Niemann-Pick disease Type $\mathrm{A}$ and $\mathrm{C}$. Biochem Biophys Res Commun 108:1101

14. Peters SP, Coyle P, Coffee CJ, Glew RH, Kuhlenschmidt MS, Rosenfeld L, Lee YC 1977 Purification and properties of a heat-stable glucocerebrosidase activating factor from control and Gaucher spleen. $J$ Biol Chem 252:563

15. Poulos A, Hudson N, Ranieri E 1983 Sphingomyelinase in cultured skin fibroblasts from normal and Niemann-Pick Type C patients. Clin Genet $24: 225$

16. Poulos A, Beckman K, Ellis DH, Pollard AC 1982 Hepatic storage of bis(monoacylglycerol) phosphate without concomitant storage of sphingomyelin in a 72-year-old patient with partial deficiency of sphingomyelinase. Clin Genet 22:234

17. Poulos A, Beckman K 1980 The bile salt activation of leukocyte sphingolipid hydrolase activity and the modifying effects of Triton X-100. Clin Chim Acta 107:27

18. Poulos A, Shankaran P, Jones CS, Callahan JW 1984 Enzymatic hydrolysis of sphingomyelin liposomes by normal and Niemann-Pick tissues. Biochim Biophys Acta, in press

19. Poulos A, Lowden JA, Callahan JW 1982 Sphingomyelin storage disease: a new classification. Proceedings of the Human Genetics Society of Australia, Adelaide (Pathology 15:104)

20. Poulos A, Ranieri E, Shankaran P, Callahan JW 1984 Studies on the activation of the enzymatic hydrolysis of sphingomyelin liposomes. Biochim Biophys Acta 793:141

21. Vanier MT, Revol A, Fichet M 1980 Sphingomyelinase activities of various human tissues in control subjects and in Niemann-Pick disease-development and evaluation of a microprocedure. Clin Chim Acta 106:257

\title{
Treatment of Experimental Group B Streptococcal Infection with Hybridoma Antibody
}

\author{
ROBERT D. CHRISTENSEN, GERALD ROTHSTEIN, HARRY R. HILL, AND SETH H. PINCUS \\ Departments of Pediatrics, Internal Medicine, and Pathology, University of Utah School of Medicine and the \\ Primary Children's Medical Center, Salt Lake City, Utah, 84132
}

\begin{abstract}
Previous studies have shown a reduction in mortality rate from $90 \%$ to zero when neonatal rats, inoculated with group B streptococci (GBS) were injected with type-specific IgM antibody. However, in those studies, the antibody was administered simultaneously with the bacteria and at the same site, unlike the situation which would exist if antibody was used clinically to treat established infection. In the present experiments, we administered antibody intraperitoneally at various intervals following intrathoracic inoculation of GBS. When antibody was administered immediately after, or up to $\mathbf{2} \mathrm{h}$ following bacterial inoculation, all animals survived. When antibody administration was delayed for 4,5 , or $6 \mathrm{~h}$, survival rates of 92,60 , and $29 \%$ were observed. When antibody administration was delayed for more than $6 \mathrm{~h}$, no survival occurred. Failure of antibody to protect animals from death
\end{abstract}

Received November 16. 1983; accepted March 19, 1984.

This work was supported by United States Public Health Service Grants HD14419, Al-13150, and AI-19094 and by two grants from the Thrashner Research Fund.

Requests for reprints may be addressed to Dr. Robert D. Christensen, Division of Hematology, University of Utah School of Medicine, 50 North Medical Drive, Salt Lake City, UT 84132. coincided temporally with profound depletion of the neutrophil storage pool. In other experiments, depletion of the neutrophil storage pool was produced by a separate, noninfectious mechanism (subcutaneous implantation of sterile polyvinyl sponge discs) after which animals were inoculated with GBS. Antibody did not provide protection from death in animals with neutrophil storage pool depletion. (Pediatr Res 18:1093-1096, 1984)

\section{Abbreviations}

GBS, group B streptococci

PBS, phosphate-buffered saline

Current treatment methods fail to produce survival in as many as $25-30 \%$ of newborn infants with "early onset" bacterial sepsis (23). Diminished host resistance, due to incomplete development of the neutrophil system $(3,4,17,26)$ and in many infants, also due to diminished opsonizing capacity $(1,16)$ certainly contributes to their refractoriness to treatment. Because of the neonate's 